Chirurgia (2019) 114: 659-663

No. 5, September - October

Copyright@ Celsius

http://dx.doi.org/10.21614/chirurgia.114.5.659

\title{
Anaplastic Thyroid Cancer: A Rare Entity Presented Clinically Only with Fever and Elevated CRP
}

\author{
Nikolaos Garmpis ${ }^{1}$, Christos Damaskos', Anna Garmpi², Aliki Liakea ${ }^{3}$, Dimitrios Mantas \\ ${ }^{1}$ Second Department of Propedeutic Surgery, Laiko General Hospital, Medical School, \\ National and Kapodistrian University of Athens, Athens, Greece \\ ${ }^{2}$ First Department of Propedeutic Internal Medicine, Laiko General Hospital, Medical School, \\ National and Kapodistrian University of Athens, Athens, Greece \\ ${ }^{3}$ First Department of Pathology, Medical School, National and Kapodistrian University of Athens, Athens, Greece
}

Corresponding author:

Nikolaos Garmpis, MD, MSc, PhD(c)

17 Agiou Thoma Street, 11527

Athens, Greece.

E-mail: nikosg22@hotmail.com

\section{Abbreviations:}

ATC - Anaplastic Thyroid Carcinoma; CRP - C-Reactive Protein;

CT - Computed Tomography;

PDTC - Poorly Differentiated Thyroid Carcinoma;

WDTC - Well Differentiated Thyroid Carcinomas;

MTC - Medullary Thyroid Cancer.

\section{Rezumat}

Cancerul tiroidian anaplazic: un caz rar având ca simptome clinice febra și un nivel ridicat al CRP

Cancerul tiroidian anaplazic (CTA) este o afecțiune rară, dar aproape invariabil letală. În studiul de față prezentăm cazul unei paciente care, pe lângă prezența guşei nodulare, a avut ca simptome clinice doar un nivel ridicat al proteinei C-reactive (CRP) şi o stare subfebrilă persistentă. Pacienta a fost supusă tiroidectomiei, şi apoi a urmat un tratament care a constat în chimioterapie şi radioterapie. La 11 luni de la intervenția chirurgicală pacienta este în viață iar boala este în remisie. Scopul nostru este de a demonstra că CTA poate fi prezent fără o simptomatologie specifică, şi de a creşte gradul de conştientizare a importanței diagnosticului precoce.

Cuvinte cheie: cancer tiroidian anaplazic, markeri inflamatori, CRP, feritină

\section{Abstract}

Anaplastic thyroid carcinoma (ATC) is a rare but almost invariably lethal disease. In this manuscript, we present a case where the dominant manifestation of ATC beside the goitre was elevated CRP values and a persistent low-grade fever. The patient underwent surgical removal of the tumour, chemotherapy and radiotherapy 
treatment. She is still alive and healthy 11 months after the surgery. We aim to demonstrate that ATC can be present with no specific symptoms or findings and to raise awareness towards an earlier diagnosis.

Key words: anaplastic, thyroid, cancer, inflammatory markers, CRP, ferritin

\section{Introduction}

Anaplastic thyroid carcinoma (ATC) is one of the most aggressive solid tumors in humans. It is a rare but extremely aggressive type of cancer that arises from the follicular cells of the thyroid gland. ATC accounts for the majority of deaths from thyroid carcinoma (1). The clinical course of ATC is characterized by aggressive local disease, high rates of metastases and rapidly fatal clinical outcomes (2). In this case we present a patient with ATC whose the only clinical symptom was fever and weight loss and the dominant abnormal laboratory test was elevated C-reactive protein (CRP). Final diagnosis in this patient was achieved only by the histological study of the thyroid gland, after the surgery.

\section{Case Report}

A 72-year-old female with an already diagnosed goiter, visited our department due to low grade fever (up to $37.5^{\circ} \mathrm{C}$ ) from a 3-month period with concomitant weight loss. Laboratory tests indicated elevated levels of inflammatory markers such as CRP (292.2 mg / l) and ferritin (496.3 ng / ml). Thyroid hormone control showed elevated levels of thyroglobulin (609.0 $\mathrm{ng} / \mathrm{ml}$ ). The X-Rays of the chest and cervical curve of the spine indicated a tracheal outflow (Fig. 1). Thyroid ultrasound (US) revealed a multi-nodular texture, with the left lobe being occupied by a nodule of $5,59 \times 2,79 \mathrm{~cm}$, without any abnormal blood flow, no cervical lymph node enlargement, nor any parathyroidal pathological finding. Further evaluation with a thoracic computed tomography (CT) scan, confirmed the ultrasound findings, describing a $9.5 \times 6 \mathrm{~cm}$ nodule in the left thyroid gland, causing impressive tracheal outflow and pressure in the esophagus (Fig. 2). The abdominal CT did not reveal any pathological findings other than simple liver cysts.

Taking into consideration all the aforementioned findings alongside the intense compressive effects and the unreduced fever, the patient was led to the surgical room where she was subjected to total thyroidectomy. During the surgical procedure, a rapid biopsy was sent but no evidence of malignancy was noted.

The patient had an uneventful postoperative course while the CRP and ferritin values returned to normal on the third postoperative day. The outcome of the histological examination revealed the unexpected diagnosis of ATC (Fig. 3) and the patient started chemotherapy (with doxorubicin and cisplatin) and radiotherapy.

Up to this date, 11 months later, the patient is alive and healthy. The follow-up US and CTs at 3 and 6 months post-operatively showed no evidence of recurrence. The patient is advised to undergo a CT scan every 3 months for the first year. If no findings of recurrence or metastasis are found, the time period between CTs will be adjusted to 6 months. As far as the CRP levels are concerned, they appear to stay within normal values.

\section{Discussion}

ATC is one of the most aggressive and lethal solid tumors known to affect humans with a disease-specific mortality approaching $100 \%$ (3). Most often it originates from unrecognized differentiated thyroid cancer. However, it could also arise spontaneously, with no previous tumor of lower grade present (4). The most 
Figure 1. The X-Rays indicating a tracheal outflow. (A) Chest X-Ray (Face); (B) Chest X-Ray (Profile); (C, D) Cervical curve $X$-Ray in which the tracheal outflow is shown
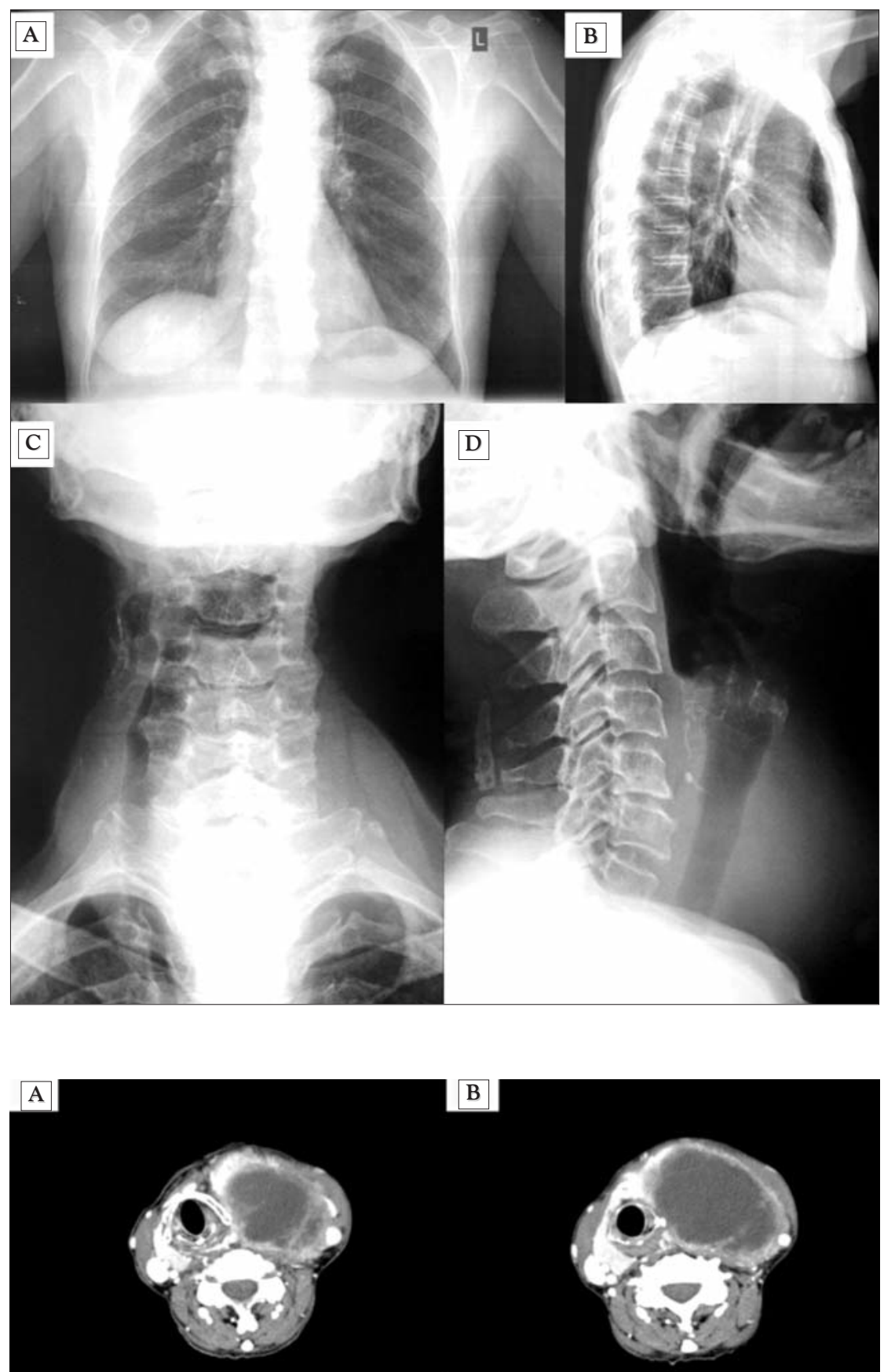

B

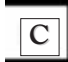

D

Figure 2. Axial computed tomography section of the neck showing the sizable thyroid mass and the tracheal outflow $(A, B, C, D)$

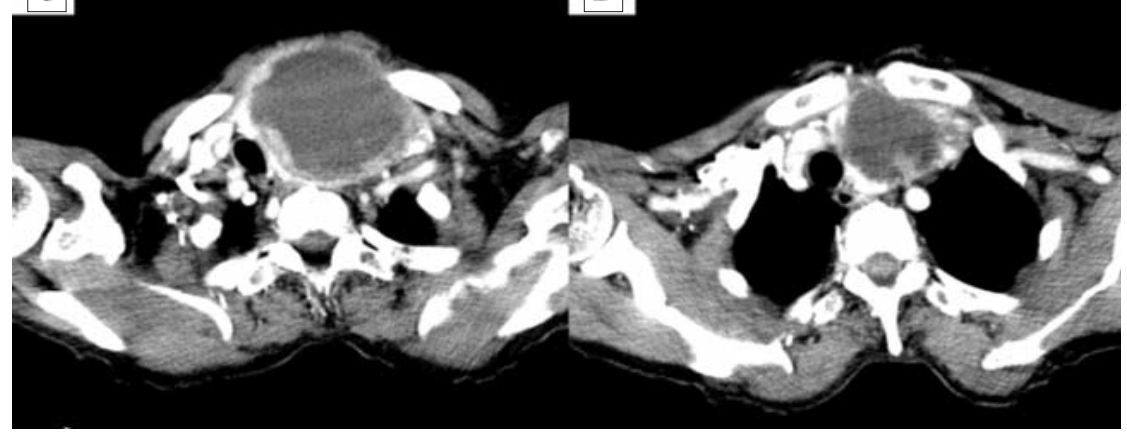


Figure 3. Histologic findings of anaplastic thyroid cancer. (A) Areas of necrosis and inflammation (Hematoxylin-Eosin, original magnification $x 40$ ); (B) Higher-power view, showing a malignant biphasic tumor composed of anaplastic epitheliod and spindle cells (Hematoxylin-Eosin, original magnification x100); (C, D) The tumor consists of highly pleomorphic cells with large nuclei, prominent nucleoli and mitotic figures (HematoxylinEosin, original magnification $\times 200$ )

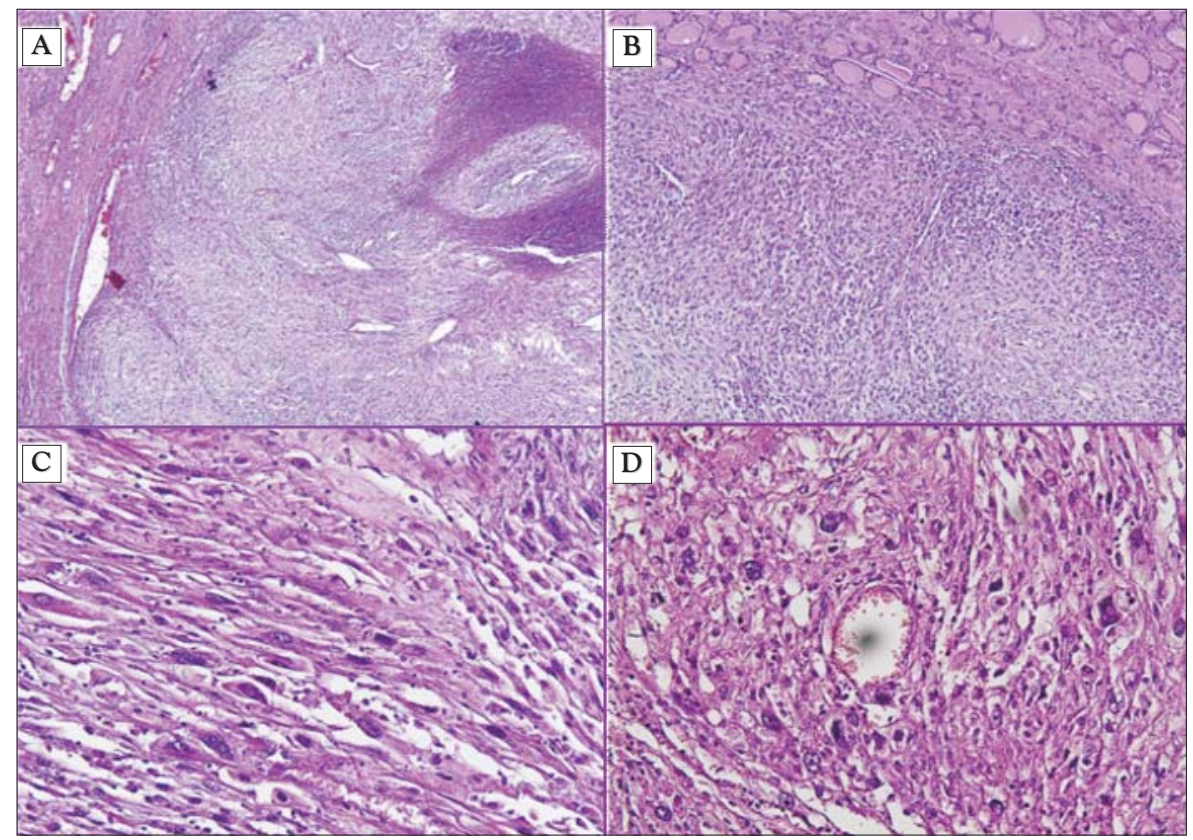

frequent clinical manifestations of ATC may be a rapidly enlarging neck mass, dyspnea, dysphagia, neck pain, Horner's syndrome, stroke, and hoarseness due to vocal cord paralysis (5).

In our case, ATC was presented with none of the aforementioned clinical signs. In the contrary, the symptoms that lead the patient to the hospital were the persistent fever and the weight loss. Even from the initial checkup, it was the elevated CRP levels that placed the suspicion of a malignancy and justified the concomitant imaging.

To our knowledge, only one other case of ATC was presented with elevated inflammation markers among other symptoms up to this date in international bibliography (Table 1) (4).

Metastases in lymph nodes and other distant organs (such as lungs and bones) are quite common. With a median survival from 4 to 12 months, the majority of patients will decease in the first year (6) mainly because of suffocation (1). Patients are usually in their $6^{\text {th }}$ or $7^{\text {th }}$ decade of life at presentation (2). It is more common in women and on patients with goiter or iodine deficiency. Age (> 70 years), tumor size $(>5 \mathrm{~cm})$, extrathyroidal expansion, presence of metastases and acute symptomatology are negative prognostic factors.

The histopathology of ATC varies from patient to patient, and often within the same tumor at the intratumoral level. These tumors generally contain a heterogeneous mixture of spindled, epithelioid and pleomorphic giant cells, which makes the diagnosis of ATC challenging for pathologists (1).

Table 1. Studies describing elevated inflammatory markers as presentation of anaplastic thyroid cancer

\begin{tabular}{|c|c|c|c|c|c|c|c|c|}
\hline Authors & Year & $\begin{array}{l}\text { Patient } \\
\text { number }\end{array}$ & Sex & Age & $\begin{array}{l}\text { Elevated inflammatory } \\
\text { marker }\end{array}$ & Treatment & DFS & OS \\
\hline $\begin{array}{l}\text { Garmpis et al. } \\
\text { (Current study) }\end{array}$ & 2019 & 1 & $F$ & $72 y$ & $\begin{array}{l}\text { CRP: } 292.2 \mathrm{mg} / \mathrm{l}) \\
\text { Ferritin: } 496.3 \mathrm{ng} / \mathrm{ml})\end{array}$ & $\begin{array}{l}\text { Total thyroidectomy, Chemotherapy } \\
\text { (doxorubicin, cisplatin), Radiotherapy }\end{array}$ & $11 \mathrm{~m}$ & $11 \mathrm{~m}$ \\
\hline Haas et al. & 2008 & 1 & $\mathrm{~F}$ & $80 y$ & $\begin{array}{l}\text { CRP: } 239.0 \mathrm{mg} / \mathrm{l}) \\
\text { Leucocytes: } 25 \text { x } 109 \text { / I) }\end{array}$ & $\begin{array}{l}\text { Surgical revision of the retropharyngeal } \\
\text { space and lymph nodes removal }\end{array}$ & $0 \mathrm{~m}$ & $0 \mathrm{~m}$ \\
\hline
\end{tabular}

DFS: Disease-free survival; OS: Overall survival; F: Female; y: Years; CRP: C-reactive protein; m: Months 
The differential diagnosis of ATC can be very broad. ATC can be confused with a large variety of thyroid lesions, including poorly differentiated thyroid carcinoma (PDTC), well differentiated thyroid carcinomas (WDTC) with uncommon patterns, Riedel thyroiditis, medullary thyroid cancer (MTC) and very unusual primary thyroid carcinomas. Other tumors that mimic ATC include some sarcomas, metastatic carcinomas from other sites, melanomas and lymphomas (7).

In general, the differential diagnosis of diseases affecting deep neck structures can be very difficult. Symptoms of inflammation dominating the clinical picture do not automatically exclude the possibility of malignancy. Accurate evaluation in the diagnostic process is necessary for proper treatment strategy. Nevertheless, an abscess formation in the neck is an unquestionable indication for prompt surgical intervention.

Although survival rates have not significantly improved over the past decades, multimodality treatment, including surgery, radiation, chemotherapy, and targeted therapy, is considered the best strategy for improving outcomes in patients diagnosed with ATC (8). An intensive and multimodal approach, which includes surgical resection, radiotherapy and adjuvant chemotherapy, seems to improve local control and survival in some patients with regionally confined ATC (9). However, this conventional multimodal approach has been demonstrated to be ineffective in patients with advanced, metastatic ATC (Stage IVC) $(9,10)$. These patients receive a greater benefit from palliative care, which remains the main method of clinical management, especially in frail and elderly patients, to relieve suffering and to improve quality of life (11).

\section{Conclusion}

Although rare, ATC remains an extremely deadly and difficult to treat malignancy. The rarity of ATC represents the major limitation in acquiring adequate patient numbers to complete prospective studies. In this regard, it becomes difficult to set a gold standard as far as treatment, prognosis and even clinical presentation of this entity. More clinical trials and prospective studies are needed in order to describe and confront this malignancy in its full extend.

\section{Conflicts of Interest and Funding}

None declared.

\section{Author Contributions}

Conceptualization, D.M.; Methodology, C.D., A.L. and D.M.; Data Curation, N.G., C.D. and A.G.; Writing - Original Draft Preparation, N.G.; Writing - Review \& Editing, N.G. and C.D.; Visualization, D.M.; Supervision, D.M.; Project Administration, D.M.

\section{References}

1. Molinaro E, Romei C, Biagini A, Sabini E, Agate L, Mazzeo S, et al. Anaplastic thyroid carcinoma: from clinicopathology to genetics and advanced therapies. Nat Rev Endocrinol. 2017:13(11):644-60.

2. Kebebew E, Greenspan FS, Clark OH, Woeber KA, McMillan A. Anaplastic thyroid carcinoma. Treatment outcome and prognostic factors. Cancer. 2005;103(7);1330-5.

3. Are C, Shaha AR. Anaplastic thyroid carcinoma: Biology, pathogenesis, prognostic factors, and treatment approaches. Ann Surg Oncol. 2006:13(4):453-64.

4. Haas V, Celakovský P, Brtková J, Hornychová H. Unusual manifestation of anaplastic thyroid cancer. Acta Medica (Hradec Kralove). 2008;51(4):233-6.

5. Keutgen XM, Sadowski SM, Kebebew E. Management of anaplastic thyroid cancer. Gland Surg. 2015;4(1):44-51.

6. Haigh PI, Ituarte P, Wu HS, Treseler PA, Posner MD, Quivey JM, et al. Completely resected anaplastic thyroid carcinoma combined with adjuvant chemotherapy and irradiation is associated with prolonged survival. Cancer. 2001;91(12):2235-42.

7. Nikiforov YE, Seethala RR. Anaplastic (Undifferentiated) carcinoma. In: Nikiforov YE, Biddinger PW, Thomson LDR, editors. Diagnostic pathology and molecular genetics of the thyroid, 2nd ed. Philadelphia: Wolters Kluwer Health/Lippincott Williams \& Wilkins, 2012. p. 263-84.

8. Kebebew E. Anaplastic thyroid cancer: rare, fatal, and neglected. Surgery. 2012;152(6):1088-9.

9. Glaser SM, Mandish SF, Gill BS, Balasubramani GK, Clump DA, Beriwal S. Anaplastic thyroid cancer: prognostic factors, patterns of care, and overall survival. Head Neck. 2016;38 Suppl 1;E208390.

10. Foote RL, Molina JR, Kasperbauer JL, Lloyd RV, Mclver B, Morris $\mathrm{JC}$, et al. Enhanced survival in locoregionally confined anaplastic thyroid carcinoma: a single-institution experience using aggressive multimodal therapy. Thyroid. 2011;21(1):25-30.

11. Smallridge RC, Ain KB, Asa SL, Bible KC, Brierley JD, Burman KD, et al.; American Thyroid Association Anaplastic Thyroid Cancer Guidelines Taskforce. American Thyroid Association guidelines for management of patients with anaplastic thyroid cancer. Thyroid. 2012;22(11):1104-39. 